\title{
Vegetable Production, Livelihood Diversification and Employment Generation in Oyo State, Nigeria
}

\author{
Oluwemimo Oluwasola ${ }^{1}$ \\ ${ }^{1}$ Department of Agricultural Economics, Obafemi Awolowo University, Ile Ife, Nigeria \\ Correspondence: Oluwemimo Oluwasola, Department of Agricultural Economics, Obafemi Awolowo University, \\ Ile Ife, Nigeria. Tel: 234-(0)803-727-4784. E-mail: oluwemimo_oluwasola@yahoo.com
}

Received: May 2, 2015 Accepted: June 5, 2015 Online Published: July 15, 2015

1doi:10.5539/jas.v7n8p165

URL: http://dx.doi.org/10.5539/jas.v7n8p165

\begin{abstract}
The study examined the importance of vegetable production on incomes, with a view to enhancing livelihood diversification and employment generation in farming communities in Nigeria. Multistage sampling procedure was used to select 100 vegetable farmers from 10 local government areas in Oyo State. Data were analysed using descriptive statistics, budgetary technique and the multiple regression model. The results revealed that vegetable farmers were relatively young with a mean age of 41.9 years, highly educated with only $11 \%$ not having formal education and had a farming experience of 11.2 years on the average. Family sizes averaged 5.8 while mean farm size was 2.6 ha. The cost analysis shows that gross margin to enterprise was $\$ 472,322.56$ with a net income of $\$ 454,564.72$. The internal rate of return was 2.33 while the benefit-cost ration was 3.33 . The major determinants of net farm income from vegetable production were educational level of farmers, experience in farming, farm size and total farm expenditure. The study concluded that while vegetable farming could be a major enterprise to diversifying livelihood opportunities among smallholder farmers it also presents opportunities for attracting the young and educated unemployed if cultivable lands, inputs, credit and social overheads that will make the farming communities liveable are provided.
\end{abstract}

Keywords: livelihood, diversification, vegetables, employment, smallholder, liveable, opportunity choices

\section{Introduction}

In spite of her enormous wealth, Nigeria is grappling with a number of development challenges especially high unemployment and increasing poverty. Currently, the unemployment rate in the country stands at $23.9 \%$ (Business Day, 2012) which constitute about 39.9 million of the estimated 170 million people. Poverty is also widespread and worsening with about $70 \%$ of Nigerians living below the poverty threshold of less than US\$1.25 a day. While unemployment is higher in the urban areas, poverty is especially severe in rural areas where up to $80 \%$ of the population live below the poverty line, social services and infrastructure are inadequate and economic choices are limited. To confront these challenges as well as diversify the economy from its dependence solely on petroleum wealth, the policy focus of the Federal Government of Nigeria has been on developing the agricultural sector with its vast potentials to ensure that farmers generated $\$ 300$ billion (US\$2 billion) as well as create 3.5 million jobs in the sector between 2011 and 2015 (National Mirror, 2012; Oluwasola, 2012). The policy drive of government is based on the increasing evidence that agricultural growth is highly effective in reducing rural poverty (World Bank, 2008; Diao et al., 2006; Hazell \& Diao, 2005) and the existing potentials of the agricultural sector including: the nations total land area of 924,000 square kilometers (98 million hectares); availability of 2.5 million hectares of land that could be brought under irrigation; and the fact that the sector employs $60 \%$ of the national labour force and accounts for $90 \%$ of the non-oil export earnings (FEPA, 1992; Federal Ministry of Water Resources (FMWR), 1995; United Nations Systems (UNS), 2001; Adewusi et al., 2009; Oluwasola, 2012).

Agriculture in Nigeria is dominated by smallholder farmers (about 60\%) who produce 90\% of Nigeria's domestic food supply (Toluyemi, 1990; Ayanwale \& Bamire, 2000). These farmers cultivate small farm sizes averaging 2 hactares (NINCID, 2006; Idachaba, 1989) using rudimentary farm tools. The scale of operation is largely subsistent but marketable surplus are exchanged for cash to purchase goods and services that cannot be produced on the farm. The near subsistence nature of the farm ensures that little is saved from the small earnings made and, without access to investible funds from formal financial institutions, farmers are not able to purchase 
modern farm inputs and equipment that can help achieve a transformation of farm operations to enhance increased commercialization and economies of scale. Farmers are also confronted with numerous challenges ranging from land tenure problems, lack of access to input supply including credit, pests and diseases, extreme weather, market shocks (O'Brien et al., 2004; Morton, 2007), post harvest losses (Okuneye, 2004) and gross shortage of rural infrastructure. Lack of rural roads impedes the marketing of agricultural commodities, prevents farmers from selling their produce at reasonable prices, and leads to spoilage of farm products. Limited accessibility cuts smallholder farmers off from sources of inputs, equipment and new technology which keeps yields low. The World Bank (1996) reported that low productivity in agriculture is the cause of high incidence of poverty in Nigeria. Farmers tend to become dependent on the forces of nature to achieve their current level of output and income which make them one of the poorest economic groups in the country (Aigbokhan, 2000). And because their existence depends largely on agriculture, any untoward occurrence that adversely affect agricultural output and productivity have significant impacts on the food security, nutrition, income and wellbeing of the smallholder farming families (Hertel \& Rosch, 2010; McDowell \& Hess, 2012). The limited opportunity choices presented by farming and the farming environment not only put farmers at risk in case of vagaries in socio-economic and ecological conditions, it also repels unemployed young educated and able bodied men.

Several policy strategies have been put in place to address the drawbacks in the farming environment and access farmers to land, farm inputs, credit, market and agricultural extension services. Some of these policy strategies include: the Agricultural Development Programmes (ADPs); the River Basin Development Authorities (RBDAs); the Directorate of Food, Roads and Rural Infrastructure (DFRRI); the National Agricultural Land Development Authority (NALDA); the National Fadama Development Programme (NFDP); the National Agricultural Technology Support Project (NATSP); the National Japanese-Assisted Rice Production Programme; the IFAD-Assisted Cassava Multiplication Programme; and the National Accelerated Industrial Crop Production Programme (NAICDP). Other programmes aimed at boosting agricultural outputs include Crop Storage and Post Harvest Technology Programme; the National Seed Service Programme; the National Livestock Development Programme (NLDP); and the Aquaculture Development Project. All these policies have emphasised the supply of inputs to traditional food and cash crops that are accepted in the land culture and food choices of consumers. Although these policy supports have had appreciable impact on food crop output and is critical to enhancing livelihoods among farming households, they did not achieve the goal of transforming the agricultural sector substantially or increasing the wellbeing of the smallholder farmers. Food imports continue to soar, farm sizes remain small, opportunity choices in the rural areas are still limited while the rural farmers who are spatially as well as financially cut-off from imported foods stand the risk of food insecurity and hunger.

The failure of policy makes it imperative to search for opportunities beyond traditionally accepted limits. This implies that there is the need for looking inwards to exploiting local opportunities that can be accepted in the urban markets or food needs in the urban sectors that local endowments can help grow. As observed by Njoku et al. (2007) and Ekong (2003), rural dwellers need to expand and diversify their sources of income and livelihood activities in order to reduce poverty. One of the major ways that smallholder farmers can achieve this is the adoption of affordable agricultural innovations, technologies and inputs that cut across the various facets of agriculture and agriculture-related enterprises. In addition, conscious efforts must be made to access smallholder farmers to regular buyers and urban markets with fair and stable prices that can motivate marginalised rural households to diversify and invest more of their labour and available capital in market-oriented farming and processing activities, that not only brings in more income but also able to attract young educated unemployed people into the farming enterprise. One such area is the growing importance of vegetable production to meet the rising demand for the product among the urban elite. Vegetables add taste and flavour as well as protein, fibre, minerals and vitamins to human diet (Oyenuga \& Fetuga, 1975) especially in a region where the consumption of starchy foods predominates. Vegetable production can make a significant difference to smallholder farmers' income and wellbeing as a proper mixture of different vegetables in a meal can make up for shortages in animal protein. It contributes to livelihood diversification and employment for farmers especially during the dry season (Obuobie et al., 2006). Coupled with these factors is the rapid increase in urbanization in Nigeria which is growing at $5.5 \%$ per annum (NPC, 2006). There is thus increasing opportunities for the commercial production of vegetables as an economic crop, yet, its production has not received attention and institutional support as is the case with food and cash crops. Vegetable production in the Oke-Ogun area of Oyo state has been on the increase as the region is well suited to the cultivation of leafy vegetables like Amaranthus (Amaranthus spp.), Celosia (Celosia argentea L.), water leaf (Talinum triangulae), bitter leaf (Veronia colorata), lettuce (Lactuca sativa) and ugwu (Telefaina occidentalis). Fruit vegetables including tomato (Lycopersicon esculentum) and okra (corchorus spp.) are also widely grown. It is thus important to investigate how developments in vegetable 
production in the region can provide the basis for generating employment among the unemployed in other regions of the State while also serving as opportunities to enlarge livelihood sources among smallholder farmers. The critical questions that will be answered include: which group of farmers are involved in vegetable production? What are the opportunities presented by vegetable production that can encourage investment and engagement by current and would be farmers? What are the factors determining the profitability of vegetable production in the study area?

\subsection{Objectives}

The main objective is to examine the importance of vegetable production on incomes, livelihood diversification and employment generation in farming communities in Nigeria. The specific objectives include:

i. Describing the socio-economic characteristics of vegetable producers;

ii. Analyzing costs and returns to vegetable production; and,

iii. Determining factors influencing the profitability of vegetable production in the study area.

\section{Materials and Methods}

The study was carried in Oke Ogun region of Oyo State, Nigeria. The State lies between latitudes $7^{\circ} 41^{\prime} \mathrm{N}$ and $8^{\circ} 48^{\prime} \mathrm{N}$ of the equator and longitudes $2^{\circ} 1^{\prime} \mathrm{E}$ and $3^{\circ} \mathrm{E}$ of the Prime Meridian with a total land area of $13,537 \mathrm{~km}^{2}$. The area experiences two climatic seasons: the rainy season which operates between March and October and the dry season which operates in the remaining months.

The region is made up of ten local government areas (LGAs) which were purposively sampled for this study. The LGAs are Saki West, Saki East, Atisbo, Itesiwaju, Iwajowa, Oriire, Oorelope, Irepo, Kajola and Iwerele. From each of the LGA, 10 vegetable farmers were randomly selected, given a total of 100 respondents. Data were obtained with the aid of well structured and pretested questionnaire.

Descriptive statistics, budgetary analysis and the multiple regression analytical techniques were used to analyse information obtained from the respondents. Descriptive statistics, including frequency counts, means and percentages were used to describe the socio-economic characteristics (including age, education level, family size, farm size) of respondents. Budgetary analysis was employed to estimate costs and returns to vegetable production using the gross margin as stated in Equation (1):

$$
\pi=T R-T C
$$

Where, $\pi=$ net income ( $)$; $T R=$ Total Revenue (price per unit $\mathrm{x}$ quantity of vegetables sold); $T C=$ total costs of production (fixed cost (FC) plus variable cost (VC)) ( $\#$ ).

Variable costs (VC) included in the analysis were expenditures on labour, seedlings, fertilizers, herbicides and transportation. Items that could be used for more than a production cycle were classified as fixed costs (FC). These included cutlasses, hoes, watering cans, and baskets.

Finally, a multiple regression model was used to estimate the socio-economic factors determining the net incomes derivable from the production of vegetables in the study area. The model was implicitly specified as,

$$
\mathrm{Y}=\mathrm{f}\left(\mathrm{X}_{1}, \mathrm{X}_{2}, \mathrm{X}_{3}, \mathrm{X}_{4}, \mathrm{X}_{5}, \mathrm{X}_{6}, \mu\right)
$$

Where, $Y=$ net income from vegetables $(\$)$; $X_{1}=$ age of respondents (years); $X_{2}=$ educational level of respondents (years spent in formal schools); $\mathrm{X}_{3}=$ household size; $\mathrm{X}_{4}=$ experience in vegetable farming (years); $\mathrm{X}_{5}$ $=$ farm size (ha); $X_{6}=$ total farm expenditure incurred $(\$) ; \mu=$ error term.

A priori expectations were for $\mathrm{X}_{2}, \mathrm{X}_{4}, \mathrm{X}_{5}$ and $\mathrm{X}_{6}$ to be positively correlated to net farm income while $\mathrm{X}_{3}$ could be either positively or negatively correlated depending on whether the family is a production or consumption unit. $\mathrm{X}_{1}$ is expected to be positively correlated to farm output to a certain age where it starts to show a negative relationship as increasing age affects the productivity of farmers.

\section{Results and Discussions}

\subsection{Socio-Economic Characteristics of Vegetable Farmers}

The age of the farmers ranged between 18 and 65 . About $46 \%$ of the respondents aged between 21 and 40 years while $51 \%$ aged between 40 and 60 years (Table 1). The mean age of the respondents was $41.9 \pm 9.74$ years. This indicates that majority of the respondents were still in their prime age and productive years which should positively affect farm size and earnings. The farmers were much younger than farmers involved in crop farming (Oluwasola, 2012; Ayanwale \& Oluwasola, 2009; Oluwasola \& Alimi, 2007; Nmadu \& Ibiejemite, 2007) suggesting the possibility of attracting younger farmers into the enterprise. Table 1 clearly shows the dominance 
of men in the enterprise as $93 \%$ of the respondents were male while only $7 \%$ were women. This could be due to the fact that vegetable farming is a very tedious and labour intensive enterprise especially in farm preparation, tillage, weeding and irrigating of plants especially during the dry season with a watering can. However gender division of labour also ensures that women are more dominant in the marketing of the vegetables. The level of literacy among the farmer respondents was very high as $75 \%$ of them had at least a secondary education including 31\% who attended higher institutions - universities, polytechnics and Colleges of Education. Only 8\% of the respondents did not have formal education as shown in Table 1. The level of literacy achieved in this study was much higher than recorded for vegetable farmers in Ile-Ife, Nigeria by Akinola et al. (2011). Although the high level of literacy among the respondents could be attributed to the high level of unemployment in the country, it portends a positive impact in farm development as farmers could easily read, write, understand and access credit opportunities as well as comprehend government policy strategies aimed at enhancing farm output, income and rural welfare. About $81 \%$ of the farmers were married while $10 \%$ were divorced. The mean household size was 5.8 \pm 2.96 . Compared to other agricultural regions in the country (Idowu \& Kassali, 2011; Aihonsu, 2002) household sizes were fairly small. While the small size of the family is also capable of enhancing savings, it could also adversely affect farm operations as household labour, which is the most dependable resource in smallholder farming enterprises may not be available especially during peak labour requirements periods thereby increasing the cost incurred on hired labour.

Table 1 also shows that $53 \%$ of the respondents saw farming as their primary occupation. The result is similar to findings by Adesiyan and Idowu (2011) among vegetable farmers in Lagos. These groups of farmers are not likely to divert assistance to farmers in terms of cash or inputs as farming is their main source of livelihood. The remaining $47 \%$ had other jobs and were probably into vegetable farming to augment income from their primary occupation. Twenty four percent were civil servants, $17 \%$ were artisans while the remaining $6 \%$ were traders. The likelihood of diversifying financial assistance to this group is very high. Farm sizes varied with $36 \%$ of the respondents farming up to 2 hectares while $29 \%$ operated a farm size of between 2.1 and 4.0 hectares. Twenty percent had a farm size of between 4.1 and 6.0 hectares; 13\% had between 6.1 and 8.0 hectares while the remaining $2 \%$ farmed more than 8 hectares. The mean farm size cultivated by the respondents was $2.6 \pm 5.85$ hectares. Although this is small, it is slightly higher than the average farm size in Nigeria (NINCID, 2006). In terms of farming experience, $24 \%$ of the respondents have been involved in vegetable farming for up to 5 years; $38 \%$ for between 5.1 and 10.0 years; $17 \%$ for between 10.1 and 15 years; $10 \%$ for between 15.1 and 20 years while the remaining $11 \%$ have been involved in vegetable farming for more than 20 years. The mean experience in vegetable farming for the respondents was $11.2 \pm 7.77$ years. Clearly, the number of years involved by farmers in vegetable farming shows the commercialization of vegetable production is fairly recent, nonetheless, the years of experience acquired by the respondents is sufficient to understand the technicalities involved in vegetable production and marketing in the region. The respondents main source of capital which they invested in the business as shown in Table 1 indicates that $63 \%$ used personal savings while $24 \%$ got financial assistance from family members and friends. Clearly, the funds used by $87 \%$ came from informal sources and they tend to be small. They are inadequate for any large scale investment in farm business. Eleven percent got loan from cooperative societies while $2 \%$ took loan from micro-finance banks. All the respondents depended on rain water to grow their vegetables during the rainy season. During the dry season however when water is scarce, farmers irrigated their farms with $73 \%$ depending on water from nearby streams and $27 \%$ on wells dug in their farms.

The major challenge confronting the vegetable producers is that of transportation (100\%) to link them up with urban markets where they could have reaped higher incomes from the high product prices. Consequently, farmers sell to middlemen and households directly. For $77 \%$ of the respondents, the main challenge was storage facilities to be able to store products when the market is not favourable or save them from spoilage. Seventy five percent also mentioned the problem of marketing as they have to endure the sharp practices of middlemen while $45 \%$ mentioned the problem of pest infestation. 
Table 1. Socio-economic characteristics of respondent farmers

\begin{tabular}{|c|c|c|c|c|}
\hline Variable & Frequency & Percentage & Cumulative Percentage & Mean \\
\hline \multicolumn{5}{|l|}{ Age } \\
\hline$<21$ & 1 & 1.0 & & \\
\hline $21-40$ years & 46 & 46.0 & 47.0 & \\
\hline $41-60$ years & 51 & 51.0 & 98.0 & 41.9 \\
\hline$>60$ years & 2 & 2.0 & 100.0 & \\
\hline \multicolumn{5}{|l|}{ Gender } \\
\hline Male & 93 & 93.0 & & \\
\hline Female & 7 & 7.0 & 100.0 & \\
\hline \multicolumn{5}{|l|}{ Level of education } \\
\hline Did not go to school & 8 & 8.0 & & \\
\hline Adult/Quaranic education & 3 & 3.0 & 11.0 & \\
\hline Primary school education & 14 & 14.0 & 25.0 & \\
\hline Secondary school education & 44 & 44.0 & 69.0 & \\
\hline Higher Institutions & 31 & 31.0 & 100.0 & \\
\hline \multicolumn{5}{|l|}{ Marital Status } \\
\hline Single & 8 & 8.0 & & \\
\hline Married & 81 & 81.0 & 89.0 & \\
\hline Widowed & 1 & 1.0 & 90.0 & \\
\hline Divorced & 10 & 10.0 & 100.0 & \\
\hline \multicolumn{5}{|l|}{ Family size } \\
\hline $1-4$ & 38 & 38.0 & & \\
\hline $5-8$ & 40 & 40.0 & 78.0 & 5.8 \\
\hline $9-12$ & 21 & 21.0 & 99.0 & \\
\hline$>12$ & 1 & 1.0 & 100.0 & \\
\hline \multicolumn{5}{|l|}{ Primary Occupation of respondents } \\
\hline Farming & 53 & 53.0 & & \\
\hline Civil Servants & 24 & 24.0 & 77.0 & \\
\hline Artisans & 17 & 17.0 & 94.0 & \\
\hline Traders & 6 & 6.0 & 100.0 & \\
\hline \multicolumn{5}{|l|}{ Farm Size (ha) } \\
\hline$\leq 2$ & 36 & 36.0 & & \\
\hline $2.1-4.0$ & 29 & 29.0 & 65.0 & \\
\hline $4.1-6.0$ & 20 & 20.0 & 85.0 & 2.6 \\
\hline $6.1-8.0$ & 13 & 13.0 & 98.0 & \\
\hline$>8.0$ & 2 & 2.0 & 100.0 & \\
\hline \multicolumn{5}{|c|}{ Farming experience of farmers (years) } \\
\hline$\leq 5$ & 24 & 24.0 & & \\
\hline $5.1-10$ & 38 & 38.0 & 62.0 & \\
\hline $10.1-15$ & 17 & 17.0 & 79.0 & 11.2 \\
\hline $15.1-20$ & 10 & 10.0 & 89.0 & \\
\hline$>20$ & 11 & 11.0 & 100.0 & \\
\hline \multicolumn{5}{|l|}{ Sources of investment capital } \\
\hline Personal savings & 63 & 63.0 & & \\
\hline Family/friends & 24 & 24.0 & 87.0 & \\
\hline Cooperatives & 11 & 11.0 & 98.0 & \\
\hline Micro-Finance Banks & 2 & 2.0 & 100.0 & \\
\hline
\end{tabular}




\begin{tabular}{lll}
\hline Sources of water for farming & & \\
Rain & 100 & 100.0 \\
Well & 27 & 17.0 \\
Stream & 73 & 73.0 \\
Constraints to vegetable production & & \\
Transportation & 100 & 100.0 \\
Storage & 77 & 77.0 \\
Marketing & 75 & 75.0 \\
Pests & 45 & 45.0 \\
\hline
\end{tabular}

Source: Field survey (2012).

\subsection{Cost and Return to Vegetable Farming}

Table 2 shows the results of the budgetary analysis. As shown the total variable cost was $\$ 177,056.65$ which at a prevailing exchange rate of $\$ 2002$ to 1 US\$ amounts to (US\$885.28). Of this, expenditure on labour alone accounted for $\$ 104,249.51$ (US\$521.24) or $58.6 \%$ of the total variable cost. There were three major expense items under labour including land preparation ( $\$ 26,508.00$ or US\$132.54), weeding ( $\$ 67,391.00$ or US\$336.96) and harvesting ( $\$ 10,350.51$ or US\$51.75). The expenditure on weeding alone constituted $38.06 \%$ of the total variable cost. Hence, accessing farmers to labour saving devices especially in smothering weed will greatly enhance profit. In addition, it will reduce the drudgery of vegetable farming. Another major expense item was fertilizer on which an average of $\$ 37,275.00$ (US\$186.38) or $21.05 \%$ of variable costs was incurred. Also, $\$ 23,442.80$ (US\$117.21) or $13.24 \%$ of total variable cost was expended in purchasing seedlings. Clearly, the level of farm operation was on commercial scale with this heavy usage of fertilizer. Other expense items were herbicide ( $\$ 6,506.00$ (US\$32.53) or $3.68 \%$ of total variable cost while transportation cost was N5,583.33(US\$27.92) or $3.15 \%$. The fixed cost component was $\$ 13,313.38$ (US\$66.57). The major expense item were hoes, cutlasses, watering cans, water hoses and baskets.

Given an average revenue of $\$ 649,379.20$ (US\$3,246.90) and an average variable costs of $\$ 177,056.64$ (US\$885.28), the gross margin to enterprise was $\$ 472,322.56$ (US\$2,361.61). The total cost incurred by respondents was $\$ 194,814.48$ (US\$974,07) leaving a net revenue of $\$ 454,564.72$ (US\$2,272.82). This gives a monthly net return of $\$ 37,880.39$ (US\$189.40) which nearly double the current minimum wage of $\$ 19,000$ (US\$95) prevailing in the country. The financial ratios in Table 2 shows that the expense-structure ratio was 0.10 indicating that for every $\$ 100$ spent on vegetable production, only $\$ 10$ was spent on fixed inputs while the remaining 90 went on variable inputs. This suggests that the farmers can easily adjust to market conditions since expenditures on variable inputs constitute a very large proportion of total costs. As variable cost constitute a very significant component of total cost of production, oscillations in the market price of variable inputs could highly impact on the gross margin obtained. Policy measures that can lead to a reduction of the variable cost especially the cost of labour and fertilizer will greatly reduce the cost of production, enhance output as more lands can be brought under cultivation which will in turn increase farm income. The Benefit-Cost ratio of 3.33 indicates that for every $\$ 100$ invested on vegetable farming, 233 will be realised in addition to what was invested suggesting that vegetable production in the study area was profitable. The rate of return of 2.33 suggests an increasing rate of return to scale with every $\$ 100$ invested returning $\$ 233$. 
Table 2. Analysis of cost and returns to vegetable production

\begin{tabular}{lll}
\hline Income/cost Items & Amount (N) & Percentage in cost category \\
\hline Revenue & $\mathbf{6 4 9 , 3 7 9 . 2 0}$ & \\
Labour: (i) Land preparation & $(26,508.00)$ & 14.97 \\
$\quad$ (ii) Weeding & $(67,391.00)$ & 38.06 \\
$\quad$ (iii) Harvesting & $(10,350.51)$ & 5.85 \\
Seedlings & $(23,442.80)$ & 13.24 \\
Herbicide & $(6,506.00)$ & 3.68 \\
Fertilizer & $(37,275.00)$ & 21.05 \\
Transportation & $(5,583.33)$ & 3.15 \\
Total variable costs & $(177,056.64)$ & \\
Gross margin & $\mathbf{4 7 2 , 3 2 2 . 5 6}$ & \\
Fixed costs items & $(13,318.38)$ & \\
Depreciation & $(4,439.46)$ & \\
Total fixed cost & $(17,757.84)$ & \\
Total Cost & $(194,814.48)$ & \\
Net revenue & $\mathbf{4 5 4 , 5 6 4 . 7 2}$ & \\
Expense-Structure Ratio & 0.10 & \\
Benefit-Cost Ratio & 3.33 & \\
Rate of Return & 2.33 & \\
\hline
\end{tabular}

\subsection{Factors Determining Income Realized in Vegetable Farming}

Equation 3 shows that all the independent variables were positively signed and in conformity with a priori expectations. Four of the variables, educational level of respondent $\left(\mathrm{X}_{1}\right)$, experience of respondents in farming $\left(\mathrm{X}_{4}\right)$, farm size $\left(\mathrm{X}_{5}\right)$ and total farm expenditure $\left(\mathrm{X}_{6}\right)$ were also statistically significant.

The educational level of respondents $\left(\mathrm{X}_{2}\right)$ was positively associated with net income from vegetable farms. The variable was also statistically significant. The coefficient of the variable indicates that a unit increase in the number of years spent in school will increase net income in vegetable farming by $48 \%$. The involvement of the educated in vegetable production is a fallout from the high unemployment rate in Nigeria. Their interest in farming is more than subsistence as they are involved to make a living. In addition, it is also expected that the educated farmers will be able to take advantage of innovations and policies aimed at enhancing farm income as well as take advantage of prevailing economic opportunities that increasing demand for vegetables in the diet of Nigerians offers. Findings by Bamire et al. (2007) supports this result while Ajala et al. (2003), pointed out that education enables individuals to gain knowledge and skills, thereby increasing their power of understanding. The experience of farmers in vegetable production $\left(\mathrm{X}_{4}\right)$ was positively associated with net income from vegetable farming and statistically significant. The coefficient of the variable indicates that a unit increase in the experience of farmers in vegetable production will lead to a corresponding increase of $35 \%$ in net income from vegetable production. As farmers experience in vegetable production increases, their efficiency at utilizing resources to achieve higher levels of output increases. They are also able to understand the dynamics in the demand and pricing of vegetables to be able to take full advantage to increase earnings and/or minimize loss. This result supports the findings of Emenyonu et al. (2012), Awotide et al. (2012) and Akinola et al. (2011). Farm size $\left(\mathrm{X}_{5}\right)$ was also positively associated with net income and statistically significant with its coefficient indicating that a unit increase in farm size will lead to $52 \%$ increase in net income. This supports the findings of Nmadu and Ibiejemite (2007), Abdu and Musa (2007) and Ajibefun and Abdulkadri (1999) who reported similar trend for different farm enterprises. There was also a positive association between total farm expenditure $\left(\mathrm{X}_{6}\right)$ and net farm income. This was however contrary to the findings of Awotide et al. (2012). This could be because the return to scale was increasing and as more expenditure was incurred in purchasing farm inputs, net income increased. The variable was also statistically significant with its coefficient indicating that a unit increase in total farm expenditure will increase net farm income by $21 \%$. Age of farmers $\left(\mathrm{X}_{1}\right)$ and the household size $\left(\mathrm{X}_{3}\right)$ were positively associated with net income but were statistically insignificant.

The adjusted coefficient of determination of 0.854 indicates that about $85 \%$ of the variability in net income 
earned from vegetable production in the study area is associated with the variables specified in the model.

$$
\begin{aligned}
& \mathrm{Y}=6.777+0.243 \ln \mathrm{X}_{1}+0.481 \ln \mathrm{X}_{2} * *+0.020 \ln \mathrm{X}_{3}+0.347 \ln \mathrm{X}_{4} *+0.523 \ln \mathrm{X}_{5} *+0.208 \ln \mathrm{X}_{6} * \\
& \begin{array}{llllll}
(0.133) & (0.194) & (0.202) & (0.139) & (0.237) & (0.114)
\end{array} \quad(0.216)
\end{aligned}
$$

$R^{2}=0.862 ; \quad \bar{R}^{2}=0.854 ;$ F-value $=97.187 ;$ N.B. * significant at $10 \%$ level; ** significant at $5 \%$ level. Figures in parenthesis are standard errors.

\section{Recommendation and Conclusion}

The study examined the economic importance of vegetable production in Oke Ogun area of Oyo State. The findings of the studies are very important for policy formulation in livelihood diversification among smallholder farmers and generating employment among the teeming unemployed especially, the educated youths. The study revealed that the vegetable farmers were younger compared to food and cash crop farmers and were also highly educated with up to $31 \%$ attending higher institutions and $75 \%$ having a minimum of school certificate. Clearly, developments in vegetable production in the area shows that younger and educated people who are unemployed can be attracted to cultivate the product given the availability of necessary economic incentives like cultivable land, inputs and credit as well as cooperant social overheads that can make the country side liveable. The farming experience of farmers averaging 11 years clearly shows these are younger and new set of farmers taking advantage of opportunities that can enhance income earnings. A further employment generating and livelihood diversification opportunities that the dominance of the male gender in vegetable production portends is that while the men folk can be involved in vegetable production, efficient transportation system will enable the women to be profitably engaged in the distribution and marketing of the vegetables. Although mean farm size of 2.6 ha cultivated in the area was just a little bit higher than the average that subsists in the country, the opportunity of producing the crop during the dry season and also maintaining food crop farms simultaneously ensures diversification of income and food sources for farmers. This is very critical for the sustainability of the smallholder farm households in ensuring income and food security. The farmers' main source of capital for investing in vegetable production came from informal sources. If the various farming programmes of government aimed at providing employment opportunities and reducing poverty like the Subsidy Reinvestment and Empowerment Programme (SURE-P) can rightly target this group and/or enterprise, the scale of farm investment will not only increase but also attract unemployed groups. The cost analysis shows that vegetable production was very profitable with income far exceeding cost of production. While the regression analysis shows that farm size was a statistically significant factor influencing vegetable production and that a unit increase in farm size will lead to $52 \%$ increase in net income, the cost analysis shows that labour was a major cost item in vegetable production. Policy measures focussed on technologies that will reduce the use of labour in expanding farm acreage cultivated by farmers will greatly enhance income in vegetable production. Finally, the education status of farmers, the years of farming experience and total farm expenditure incurred by farmers were significant determinants of the net income derived from vegetable farming. This further make case for putting in place policies and programmes that will attract the young and educated into vegetable farming business.

\section{References}

Abdu, Z., \& Musa, S. A. (2007). Socio-economic Determinants of Soyabean Production in Bauchi State: The Case of Dass and Toro Local Government Areas (pp. 27-35). Refereed Conference Proceedings of the Nigerian Association of Agricultural Economists (NAAE).

Adesiyan, A. T., \& Idowu, E. O. (2011). Urban Agriculture and Household Food Security in Lagos Metropolis, Nigeria. In R. Adeyemo (Ed.), Urban Agriculture, Cities and Climate Change (pp. 132-137). Cuvillier Verlag, Gottingen.

Adewusi, S. R. A., Ilori, M. O., \& Oluwasola, O. (2009). Climate change and the maximization of Nigeria's food resources. In C. O. Adebooye, K. A. Taiwo, \& A. A. Fatufe (Eds.), Biotechnology Development and threat of Climate Change in Africa: The Case of Nigeria (Vol. 2, pp. 177-188). Cuvillier Verlag, Gottingen

Aigbokhan, B. E. (2000). Determinants of Poverty in Nigeria. DPC Research Report No. 22. Development Policy Centre, Ibadan.

Aihonsu, J. O. Y. (2002). Comparative Economic Analysis of Upland and Swamp Rice Production Systems in Ogun State, Nigeria (Ph.D Agricultural Economics Thesis). Department of Agricultural Economics, Obafemi Awolowo University, Nigeria.

Ajala, M. K., Gefu, J. O., \& Okaaito, P. O. (2003). Socio-economic Factors Influencing Small Ruminant Management Practices in Giwa Local Government Area, Kaduna State, Nigeria. Proceedings of Nigeria 
Society for Animal Production, 28, 432-435.

Ajibefun, I., \& Abdulkadri, O. A. (1999). An Investigation of Technical Efficiecy of Production of Farmers under the National Directorate of Employment in Ondo State, Nigeria. Applied Economics Letter, 6, 111-114. http://dx.doi.org/10.1080/135048599353735

Akinola, A. A., Akinwole, O. T., \& Bamire, A. S. (2011). Effects of Organic and Inorganic Fertilizers on the Productivity of Amaranthus Cruentus in Ile-Ife, Osun State, Nigeria. In R. Adeyemo (Ed.), Urban Agriculture, Cities and Climate Change (pp. 114-118). Cuvillier Verlag, Gottingen.

Awotide, D. O., Ambali, O. I., \& Aihonsu, J. O. Y. (2012). Agricultural Credit Access and Utilization among Small-Scale Fish Farmers in Egba Division of Ogun State, Nigeria (pp. 306-311). Refereed Conference Proceedings of the Nigerian Association of Agricultural Economists (NAAE).

Ayanwale, A. B., \& Bamire, A. S. (2000). Rural Incomes, Savings and Investment Behaviour among Farmers in Osun State of Nigeria. Indian Journal of Economics, 320, 49-60.

Ayanwale, A. B., \& Oluwasola, O. (2009). Socio-economic Factors Determining Upland Rice Production in Small Holder Agriculture in Osun State, Nigeria. Ife Journal of Agriculture, 24, 79-96.

Bamire, A. S., Oluwasola, O., \& Adesiyan, A. T. (2007). Landuse and Socioeconomic Determinants of Technical Efficiency of Rice Farms in Osun State, Nigeria (pp. 27-35). Refereed Conference Proceedings of the Nigerian Association of Agricultural Economists (NAAE).

Business Day. (2012). Lagos, Nigeria. Retrieved March 30, 2012, from http://www.businessdayonline .com

Diao, X., et al. (2006). The Role of Agriculture in Development: Implications for SSA. Washington DC: IFPRI.

Ekong, E. E. (2003). Rural Sociology: An introduction and analysis of rural Nigeria. Uyo: Dove Educational Publication, Nigeria.

Emenyonu, C. A., Eze, C. C., Egwuelu, C. J., \& Onyemauwa, S. C. (2012). Comparative Effects of Current Bank Reforms among Union and First Banks Farmers in Imo State, Nigeria (pp. 294-305). Refereed Conference Proceedings of the Nigerian Association of Agricultural Economists (NAAE).

Federal Environmental Protection Agency (FEPA). (1992). Transition to Sustainable Development in Nigeria. Report of the United Nations Conference on Environment and Development, Rio de Janeiro, Brazil.

Federal Ministry of Water Resources (FMWR). (1995). National Survey on Irrigation in Nigeria. FMWR, Lagos, Nigeria.

Hazell, P., \& Diao, X. (2005). The Role of Agriculture and Small Farms in Economic Development. Paper presented at The Future of Small Farms Research Workshop, Wye College.

Hertel, T. W., \& Rosch, S. D. (2010). Climate Change, Agriculture and Poverty. Policy Research Working Paper 5468. Washington D.C., World Bank. http://dx.doi.org/10.1596/1813-9450-5468

Idachaba, F. S. (1989). The Implications of Forest Fires and Bush Burning for Nigerian Food Production Strategies (No. 2, pp. 7-21). Lecture delivered on the occasion of World Environment Day, Lagos, FEPA Special Publication.

Idowu, E. O., \& Kassali, R. (2011). Determinants of farm income in peri-urban agriculture of Ile-Ife, Osun State, Nigeria. In R. Adeyemo (Ed.), Urban Agriculture, Cities and Climate Change (pp 75-80). Cuvillier Verlag Cottingen, Germany.

MaDowell, J. Z., \& Hess, J. J. (2012). Accessing Adaptation: Multiple Stressors and Livelihoods in the Bolivian Highlands under a Changing Climate. Global Environment Change, 22, $342-352$. http://dx.doi.org/10.1016/j.gloenvcha.2011.11.002

Morton, J. F. (2007). The impacts of Climate Change on Smallholder and Subsistence Agriculture (Vol. 104, 19680-19685). Proceedings of the National Academy of Science, U.S.A. http://dx.doi.org/10.1073/pnas.0701855104

National Mirror. (2012). Lagos Nigeria. Retrieved March 30, 2012, from http://www.nationalmirror online.net

National Population Commission (NPC). (2006). 2006 Nigeria's National Census. NPC, Abuja.

National Population Commission (NPC). (2006). Nigeria's National Census. Abuja, Nigeria.

Nigerian National Committee on Irrigation and Drainage (NINCID). (2006). Annual Report, 2006. Abuja.

Njoku, E. C., M., \& Adesope, C. O. N. (2007). Livelihood diversity strategies of rural women in Imo State, 
Nigeria. The Nigerian Journal of Agricultural Extension, 10, 117-123.

Nmadu, J. N., \& Ibiejemite, J. O. (2007). Economic Analysis of Fertilizer Use on Yam Production in Kabba Bunu Local Government Area of Kogi State, Nigeria (pp. 11-14). Refereed Conference Proceedings of the Nigerian Association of Agricultural Economists (NAAE).

O'Brien, K., et al. (2004). Mapping vulnerability to multiple stressors: Climate Change and Globalization in India. Global Environment Change, 14, 303-313. http://dx.doi.org/10.1016/j.gloenvcha.2004.01.001

Obuobie, E., Keraita, B., Danso, G., Amoah, P., Cofie, O. O., Raschid-Sally, L., \& Drechsel, P. (2006). Irrigated Urban Vegetable Production in Ghana: Characteristics and Risks. IWMI-RUAF-CPWF, Accra, Ghana.

Okuneye, P. A. (2004). Rising Cost of Food Prices and Food Insecurity in Nigeria and its Implication for Poverty Reduction. CBN Econ. Finan. Rev., 39(4), 25-32.

Oluwasola, O. (1999). Implications of Peasant Agricultural Practices for Environmental Resources, Food Security and Agriculturally Sustainable Development in Nigeria (pp. 197-206). Refereed Conference Proceedings of the Nigerian Association of Agricultural Economists (NAAE).

Oluwasola, O. (2012). Integrating smallholder food crop farmers into the national policy for commercialization and large scale agriculture in Nigeria: A case study of Ekiti State. International Journal of Agriculture and Forestry, 2(5), 247-256.

Oluwasola, O., \& Alimi, T. (2007). Financial Intermediation in Agriculture in Nigeria: Emerging Role of Non-Governmental Organizations (NGOs). Agrosearch. A Journal of Agriculture, Food and Development, 9(1\&2), 43-51.

Oyenuga, V. A., \& Fetuga, B. L. (1975). Dietary Importance of Fruits and Vegetables (pp. 122-123). Proceedings of the First National Seminar on Fruits and Vegetables, Ibadan, Nigeria.

Toluyemi, T. (1990). Food for all in Nigeria: A Grassroot Agricultural Financing Option. Paper presented at the National Seminar on Agricultural Financing and Credit Management, Kaduna, Nigeria.

United Nations System in Nigeria (UNS). (2001). Nigeria: Common Country Assessment, March 2001. UNDP, Lagos.

World Bank. (1996). Nigeria: Poverty in the most of plant. The challenges of growth with inclusion. A World Bank poverty assessment, Washington, D. C., World Bank.

World Bank. (2008). World Development Report 2008: Agriculture for Development. Washington DC: World Bank. http://dx.doi.org/10.1596/978-0-8213-7675-1

\section{Copyrights}

Copyright for this article is retained by the author(s), with first publication rights granted to the journal.

This is an open-access article distributed under the terms and conditions of the Creative Commons Attribution license (http://creativecommons.org/licenses/by/3.0/). 